\title{
Purine Metabolism in Friedreich's Ataxia
}

\author{
P. DRAPER, B. LEMIEUX, I. H. FOX AND D. SHAPCOTT
}

SUMMARY: In a detailed investigation of nucleotide synthesis, interconversion and degradation, no difference was found between subjects with Friedreich's Ataxia and normal controls. It appears improbable that this disorder is related to a primary defect in purine metabolism.

RESUMÉ: Une investigation détaillée de la synthèse, de l'interconversion et de la dégradation des nucléotides montre qu'il n'existe aucune différence entre les sujets avec l'ataxie de Friedreich et les sujets contrôles normaux. Il semble donc improbable que cette maladie soit reliée à un défaut primaire du métabolisme des purines.

From Le Centre Hospitalier Universitaire de Sherbrooke and the Purine Research Laboratory, Wellesley Hospital, Toronto.

Reprint requests for the complete supplement on Friedreich's ataxia (Phase Two, Part One) to: Dr. André Barbeau, Clinical Research Institute of Montreal, 110 Pine Avenue West, Montreal, Quebec, Canada H2W IR7.
Inborn errors of purine metabolism are an important source of new discoveries in general genetic diseases as were the inborn errors of amino acid metabolism two decades ago. At least 23 enzymes are know to be involved in purine metabolism and more than 10 enzyme deficiencies have been described, both in man and animal (Henderson et al., 1974) (Table 1). Further discoveries should be expected with the new advances in methodology.

\section{TABLE}

Inborn Errors of Purine Metabolism

Purine Synthesis "De Novo",

1. PRPP Synthetase Mutant

2. Glutamic PRPP Aminotransferase Mutant

Nucleotide Interconversion:

?

"Salvage" Pathway:

1. Lesch-Nyhan Syndrome: total HGPRT deficiency (EC 2.4.2.8.)

2. Lesch-Nyhan Variants: partial HGPRT deficiency

3. APRT deficiency (EC 2.4.2.7.)

Purine Catabolism:

1. Adenosine Deaminase (EC 3.5.4.4.) deficiency

2. Xanthine Oxidase deficiency (EC 1.2.3.2.)

3. Increased xanthine oxidase activity

Purine syndromes associated with central nervous system (CNS) diseases are being reported with increasing frequency since the first publication by Lesch and Nyhan (1964) of a deficiency of the enzyme hypoxanthine-guanine - phosphoribosyltransferase (HGPRT; EC 2.4.2.8.). A review by Coleman et al. (1974) revealed more than 12 distinct entities with different CNS involvement, including spino-cerebellar and cerebellar signs (Kelley et al., 1968; Rosenberg et al., 1970; Haslam and Clark, 1971) (Fig. 1).
Farstad et al. (1965a, 1965b) have shown an increase of uric acid in cerebrospinal fluid (CSF) of patients with atrophic progressive CNS degenerations, but without specific mention of the various spinocerebellar degenerations.

In search for a possible derangement of purine metabolism in Friedreich's ataxia, we undertook to screen blood, CSF and urine for changes in purines and their metabolites and altered activity of the enzymes involved in regulation of purine metabolism (Table 2).

\section{SUBJECTS AND METHODS}

Fasting urine and blood samples were taken from fifteen typical Friedreich's ataxia patients (group Ia), seventeen intra familial controls, twelve external controls, four atypical ataxia patients (group II) and two atypical intra familial controls. The subjects had been on a high carbohydrate diet for three days in preparation for the glucose tolerance test.

Plasma and urine uric acid, as well as plasma and urine creatinine values, were obtained for these subjects. Plasma and urine uric acid were determined by the alkaline phosphotungstate method (Tietz, 1970). Plasma and urine creatinine were determined by the Jaffe reaction (O'Brien et al., 1968 and Henry et al., 1974, respectively).

Incubations with radioactive purines were done on red cells from five of the typical Friedreich's ataxia patients (four females, one male, mean age eighteen years) and from five of the external control subjects (four females, one male, mean age twenty-four) using the method described by Henderson et al. (1974). Nucleotide profiles were measured for six of the typical Friedreich's ataxia patients (four females, two 
TABIE 3

URIC ACID-CREATININE (MEAN \pm S.D.)
PIASMA

URIC ACID, mg\% CREATININE, mg

\author{
$5.43 \pm 1.14$
}

$(n=14)$

$5.12 \pm 1.33$

$(\mathrm{n}=17)$

$5.1 \pm 0.89$

( $\mathrm{n}=12$ )

Typical Friedreich's

Intra Familial

controls

External Controls
$0.64 \pm 0.11$

$(\mathrm{n}=15)$

$0.68 \pm 0.13$

$0.80 \pm 0.10$

( $\mathrm{n}=12$ ) $(n=15)$
URINE

URIC ACID/CREATININE

$$
\begin{gathered}
0.36 \pm 0.13 \\
(n=13) \\
0.37 \pm 0.13 \\
(n=16) \\
0.36 \pm 0.12 \\
(n=12)
\end{gathered}
$$

TABLE 4

PURINES IN CSF ( $\mu \mathrm{g} / \mathrm{ml}$ l)

\section{GROUPS}

A. Friedreich's ataxia (group Ia)

mean ( $n=15$ determinations)

range

B. Ataxia (Group II)

mean ( $n=5$ determinations)

range

C. Non neurological controls

mean ( $n=3$ determinations)
range

1.9

$1.2-2.7$ blood-brain-barrier is not freely permeable to purines, although whether there is some degree of active transport into the CNS remains to be established (Nakagawa and Guroff, 1973; Silbernagel et al., 1977).

Coleman et al. (1974) have recently reviewed patients with hyperuricemia or hyperuricosuria and CNS symptoms. In most cases, the specific metabolic defect awaits definition. Two cases with spinocerebellar degeneration (Rosenberg et al., 1970) and which were considered to be variants of the Lesch-Nyhan syndrome, have since been shown to have no progression of their clinical state (Nyhan, 1977). The HGPRT activity was also normal in cases of olivo-pontocerebellar ataxia. Nyhan considers there is probably no relationship between HGPRT and spinocerebellar disease. In other neuromuscular diseases (Huntington's Chorea and Muscular Dystrophy). (Lemieux and Shapcott, 1973; Thomson and Smith, 1976), purine metabolism may be implicated, possibly as a secondary factor. Although raised CSF uric acid levels have been reported in atrophic progressive degenerative disease of the CNS (Farstad et al., 1965a, 1965b), it appears unlikely that this represents de novo formation within the brain, in view of the low xanthine oxidase activity in CNS tissue.

As Seegmiller has emphasized (1974), normal uric acid levels do not necessarily mean normal brain purine metabolism and the possibility of intracellular deficiency of nucleotide levels and catabolism must be considered (see also Rosembloom et al., 1967).

In our patients there was no evidence for impairment of purine synthesis as shown by normal blood levels and urinary excretion of uric acid. Normal activity of the key salvage pathway enzymes (APRT and HGPRT) in erythrocytes confirm that this pathway is not altered in Friedreich's ataxia. While it was not possible to measure the activity of each enzyme involved in purine metabolism, the interconversion of radioactive purine bases into inter- 
TABIE 5

CONCENIRATION OF NUCIBOTIDES IN RED CEIIS (umoles/ml)

\begin{tabular}{|c|c|c|c|}
\hline FRIF & EICH'S ATAXIA & & NIROLS \\
\hline & $(n=6)$ & & $=6)$ \\
\hline MEAN & (RANGE) & MEAN & (RANGE) \\
\hline 0.032 & $(0.011-0.063)$ & 0.044 & $(0.010-0.082)$ \\
\hline 0.25 & $(0.14-0.45)$ & 0.26 & $(0.16-0.32)$ \\
\hline 1.01 & $(0.80-1.22)$ & 1.02 & $(0.83-1.11)$ \\
\hline 0.013 & $(0-0.024)$ & 0.014 & $(0.009-0.019)$ \\
\hline 0.049 & $(0.023-0.076)$ & 0.048 & $(0.026-0.060)$ \\
\hline 0.174 & $(0.08-0.26)$ & 0.186 & $(0.08-0.39)$ \\
\hline 0.047 & $(0.022-0.079)$ & 0.044 & $(0.013-0.083)$ \\
\hline 0.040 & $(0.030-0.062)$ & 0.044 & $(0.031-0.056)$ \\
\hline
\end{tabular}

TABLE 6

APFT AND HGPRT ACTTVITIES (n mole $/ \mathrm{h} / \mathrm{mg}$ ) IN FRIEDREICHS ATAXIA

\begin{tabular}{lll} 
FRIEDRETCHS ATAXTA & APRT & HGPRT \\
\hline F.P. & 15.0 & 67.5 \\
T.J. & 16.5 & 65.9 \\
F.D. & 14.9 & 63.1 \\
M.Y. & 12.6 & 76.2 \\
F.B. & 14.1 & 51.8 \\
F.S. & 16.9 & 61.5 \\
F.A. & 19.1 & 62.4 \\
F.L. & 19.6 & 64.1 \\
M.G. & 15.8 & 74.6 \\
H.G. & 24.1 & 85.9 \\
H.M. & 14.3 & 54.4 \\
H.M. & 19.7 & 69.2
\end{tabular}

NOPMAL RANGE

$10.8-38.0$

$54.1-120.5$

TABLE 7

RADIOACTIVE METABOLITES IN ERYTHROCYTES (MEAN, RANGE, $n$ moles/g HEMOGLOBIN)

IN 5 FRIEDREICH'S ATAXIA AND 5 CONIROL SUBJECTS

PRECURSOR:

$\underline{\mathrm{ADE}-8-{ }^{14} \mathrm{C}}$

GUA-8- ${ }^{14} \mathrm{C}$

$\underline{\text { HYP }-8-{ }^{14} \mathrm{C}}$

METABOLITE

FRTEDREICH'S CONTROL

FRIEDREICH'S

CONIROL

FRIEDREICH'S CONIROL

\begin{tabular}{|c|c|c|c|c|c|c|c|c|c|c|c|c|}
\hline ATP & 214 & $(95-356)$ & 339 & $(143-439)$ & 11 & $(3-32)$ & 9 & $(3-16)$ & & $(1-16)$ & 9 & $(7-12)$ \\
\hline$A D P$ & 124 & $(38-201)$ & 154 & $(70-240)$ & 3 & $(0-7)$ & 4 & $(0-8)$ & 4 & $(0-11)$ & 4 & $(0-13)$ \\
\hline GIP & 11 & $(3-19)$ & 8 & $(3-16)$ & 415 & $(169-578)$ & 661 & $(561-733)$ & 12 & $(2-21)$ & 10 & $(6-17)$ \\
\hline GDP & 15 & $(7-29)$ & 18 & $(9-23)$ & 77 & $(27-191)$ & 124 & $(93-148)$ & 1 & $(0-5)$ & 1 & $(0-4)$ \\
\hline GMP & 6 & $(1-10)$ & 7 & $(4-12)$ & 16 & $(3-28)$ & 22 & $(8-34)$ & 10 & $(8-13)$ & 17 & $(9-36)$ \\
\hline IMP & 16 & $(4-33)$ & 16 & $(8-29)$ & 70 & $(32-110)$ & 116 & $(88-150)$ & 283 & $(210-337)$ & 341 & $(230-505)$ \\
\hline XMP & 3 & $(0-6)$ & 4 & $(2-7)$ & 2 & $(0-5)$ & 7 & $(0-13)$ & 2 & $(0-5)$ & 5 & $(1-16)$ \\
\hline$A D O$ & & & & & & & & & 13 & $(3-22)$ & 4 & $(0-7)$ \\
\hline$A D E$ & & & & & & & & & 9 & $(0-17)$ & 4 & $(0-14)$ \\
\hline GUO & & & & & & & & & 10 & $(6-24)$ & 16 & $(2-24)$ \\
\hline$G(A)$ & & & & & & & & & 12 & $(0-39)$ & 8 & $(0-22)$ \\
\hline INO & & & & & & & & & 81 & $(28-114)$ & 104 & $(34-141)$ \\
\hline XAO & & & & & & & & & 12 & $(0-28)$ & 14 & $(0-27)$ \\
\hline XAN & & & & & 137 & $\begin{array}{l}(99-160) \\
\mathrm{d}=3\end{array}$ & 97 & $\begin{array}{l}(50-157) \\
n=4\end{array}$ & & & & \\
\hline
\end{tabular}


mediates was normal. Finally, the CSF levels of the end products of purine metabolism in the CNS xanthine and hypoxanthine - were normal in Friedreich's ataxia.

\section{ACKNOWLEDGEMENTS}

We would like to acknowledge the excellent technical help of Mrs. G. Carrier and Miss J. Stankova. The studies reported in this paper were supported in part by a grant from l'Association Canadienne de l'Ataxie de Friedreich.

\section{REFERENCES}

BERLIN, R. D. (1969). Purine: Active transport by isolated choroid plexus. Science, 163, 1194.

COLEMAN, M., LANGREBE, $M$. and LANGREBE, A. (1974). Progressive seizures with hyperuricosuria reversed by allopurinol. Arch. Neurol., 31, 238-242.

DRAPER, P., LEMIEUX, B. and SHAPCOTT, D. (1978). Measurement of purine and their metabolites in biological materials by high pressure liquid chromatography (HPLC). To be published.

FARSTAD, M., HAUG, J. O., LINKBAK, H. and SKAUG, O. E. (1965a). Uric acid in the cerebrospinal fluid in cerebral atrophy. Acta Neurol. Scand., 41, 52-58.
HASLAM, R. H. A. and CLARK, D. B. (1971). Progressive cerebellar ataxia associated with Hand-Schuller-Christian Disease. Rev. Med. Child Neurol., 13, 174-179.

HENDERSON, J. F., FRASER, J. A. and McCOY, E. (1974). Methods for the study of purine metabolism in human cells in vitro. Clin. Biochem. 7, 339-358.

HENRY, R. J., CANNON, D. C. and WINKELMAN, J. W. (eds) (1974). Clinical Chemistry: Principles and Technics, 2nd edition, Harper and Row, New York, p. 528.

KELLEY, W. N., GREENE, M. L. and ROSENBLOOM, F. M. (1969). Hypoxanthineguanine phosphoribosyltransferase deficiency in gout. Ann. Intern. Med., 70, 155-206.

LEMIEUX, B. and SHAPCOTT, D. (1973). Purine metabolism in Huntington's Chorea. In: Huntington's Chorea 1872-1972, edited by Barbeau, A., Chase, T. N. and Paulson, G. W. Vol. I, Advances in Neurology, Raven Press, New York.

LESCH, M. and NYHAN, L. (1964). A familial disorder of uric acid metabolism and central nervous system function. Amer. J. Med., 36, 561-570.

NAKAGAWA, S. and GUROFF, G. (1973). The uptake of purine by rat brain in vivo and in vitro. J. Neurochem., 20, 1143-1149.

NYHAN, W. (1977). Ataxia and disorders of purine metabolism (abstracts). Symposium on Inherited Ataxias, Los Angeles, Cal., Nov. 2-4.

O'BRIEN, D., IBBOTT, F. A. and RODGERSON, D. O. (eds) (1968). Laboratory Manual of Pediatric MicroBiochemical Techniques, 4th edition, Harper and Row, New York, p. 111.

ROSEMBLOOM F. A., KELLEY, W. N., MILLER, J. (1967). Inherited disorder of purine metabolism: Correlation between central nervous system dysfunction and biochemical defects. J. Amer. Med. Ass., 202, 175-177.

ROSENBERG, A. L., BERGSTROM, L., TROOST, B. T. (1970). Hyperuricemia and neurologic deficits. A family study. New Engl. J. Med., 282, 992-997.

SEEGMILLER, J. E. (1974). Diseases of purine and pyrimidine metabolism. In: Duncan's Disease of Metabolism, edited by P. K. Bondy and L. E. Rosenberg. Philadelphia, Saunders.

SILBERNAGEL, G., LANG, F. and GREGER, R. (eds) (1977). Amino acid transport and uric acid transport. Georg Thieme, Stuttgart.

THOMSON, W. H. S. and SMITH, I. (1976). $\mathrm{X}$-linked recessive (Duchenne) muscular dystrophy and purine metabolism. Lancet, 1, 805-806.

TIETZ, N. W. (ed) (1970). Fundamentals of Clinical Chemistry. Saunders, Philadelphia, p. 726. 